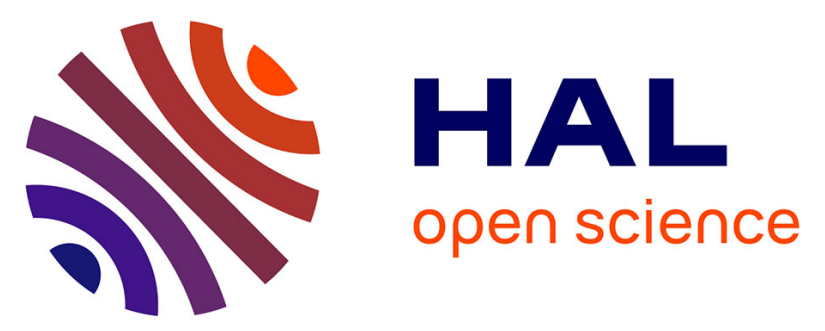

\title{
Air-blown gasification of Solid Recovered Fuels (SRFs) in lab-scale bubbling fluidized-bed: Influence of the operating conditions and of the SRF composition
}

\author{
Maxime Hervy, Damien Remy, Anthony Dufour, Guillain Mauviel
}

\section{- To cite this version:}

Maxime Hervy, Damien Remy, Anthony Dufour, Guillain Mauviel. Air-blown gasification of Solid Recovered Fuels (SRFs) in lab-scale bubbling fluidized-bed: Influence of the operating conditions and of the SRF composition. Energy Conversion and Management, 2019, 181, pp.584-592. 10.1016/j.enconman.2018.12.052 . hal-01969508

\section{HAL Id: hal-01969508 \\ https://hal.univ-lorraine.fr/hal-01969508}

Submitted on 4 Jan 2019

HAL is a multi-disciplinary open access archive for the deposit and dissemination of scientific research documents, whether they are published or not. The documents may come from teaching and research institutions in France or abroad, or from public or private research centers.
L'archive ouverte pluridisciplinaire HAL, est destinée au dépôt et à la diffusion de documents scientifiques de niveau recherche, publiés ou non, émanant des établissements d'enseignement et de recherche français ou étrangers, des laboratoires publics ou privés. 
Air-blown gasification of Solid Recovered Fuels (SRFs) in lab-scale bubbling fluidized-bed: influence of the operating conditions and of the SRF composition Maxime Hervy, Damien Remy, Anthony Dufour, Guillain Mauviel*

LRGP, CNRS, Université de Lorraine, ENSIC, 1, Rue Grandville, Nancy, France

Corresponding author at: guillain.mauviel@univ-lorraine.fr

\section{Abstract}

This article investigates the gasification of Solid Recovered Fuels (SRFs). To better understand the influence of SRF composition on gasification efficiency and syngas quality, two industrial SRFs having different compositions were studied. A detailed SRF characterization was performed (elemental analysis; ash composition; LHV; fraction of biomass, non-biomass, and inert materials) to precisely describe the chemical complexity of such materials. The gasification tests were performed at pilot-scale in a bubbling fluidized bed using air as gasifying agent, and olivine as bed material. The separate contribution of gasification temperature $\left(\mathrm{T}=750-900^{\circ} \mathrm{C}\right)$ and equivalence ratio $(\mathrm{ER}=0.21-0.35)$ on the gasification efficiency was investigated by sequentially varying these two parameters.

Gasification tests revealed that the LHV of the syngas and the cold gas efficiency decreased by $45-50 \%$ and by $20-30 \%$, respectively, with rising equivalence ratio. These evolutions were attributed to syngas oxidation reactions which promoted the formation of $\mathrm{CO}_{2}$. Indeed, mass balances calculation revealed that the part of carbon atoms in syngas in the form of $\mathrm{CO}_{2}$ rises from 43 to $54 \%$ for $\mathrm{SRF} 1$, and from 35 to $50 \%$ for SRF2. High plastic content in SRF2 was responsible for the formation of stable light hydrocarbons $\left(\mathrm{CH}_{4}, \mathrm{C}_{2} \mathrm{H}_{4}\right.$ and $\left.\mathrm{C}_{6} \mathrm{H}_{6}\right)$ from the decomposition of the plastic polymer chains, and to lower amount of $\mathrm{H}_{2}$ compared to syngas from biomass-rich SRF1. The carbon conversion decreased by $8 \%$ with rising ER from 0.21 to 0.30 for SRF2, as a result of plastics-biomass interactions promoting secondary reactions and leading to char formation. For both SRFs, rising temperature significantly improved the gasification efficiency whatever the SRF composition, and decreased the $\mathrm{CO}_{2}$ concentration. These evolutions were attributed to the promotion of several reactions, such as gasification, steam and dry reforming, Boudouard reaction, and Reverse Water-Gas Shift reaction.

\section{Introduction}

Nowadays, the worldwide MSW generation is around 1.3 billion tons per year, and is expected to reach 2.2 billion tons per year by 2025 [1]. Despite the recent progresses in waste management, the collection, recycling and valorization of waste still have to be strongly improved. Indeed, around $47 \%$ of the wastes generated in EU are disposed in landfill sites [2], leading to air and soil pollution. In order to manage the increasing worldwide generation of municipal solid wastes, new solutions must be 
developed. Thermal treatment plants, such as incineration, are essential for the management of municipal wastes [3,4]. In a comprehensive review, Arena summarized the main advantages of thermal treatments, including: (a) the reduction of waste mass and volume leading to significant saving of land compared to landfilling, (b) the destruction of contaminants, or (c) the concentration of inorganic species in the ashes [5]. Incineration is the most known and optimized thermal process as it is operated at industrial scale for many years. However, gasification process appears as a promising way for waste valorization due to the numerous applications existing for the gasification gas, named syngas. While flue gas from combustion can be valorized solely by transferring its thermal energy to heat carriers (typically steam), the syngas can be used as a fuel in high efficiency processes such as gas engine, gas turbine, fuel cell, or as a precursor for liquid fuel synthesis (via the Fischer-Tropsch reaction) and chemicals production (methanol). Another advantage of gasification is that the syngas can be valorized under different forms in other times and places, while the heat produced by combustion must be consumed directly.

Solid recovered fuels (SRFs) consist of a mixture of non-hazardous solid wastes, such as plastics, textiles, tires, paper and carton, biomass waste, or sludge. SRFs are very complex and heterogeneous materials, and the fraction of each component can vary significantly depending on the waste origin, the season, the waste separation plant, and the SRF production technique. SRFs represent a significant waste resource, estimated at 90 million tons per year in France. The production of energy from the nonrecyclable fraction of the SRF thus appears as an attractive solution for waste management. The high diversity of SRFs chemical composition does not allow to precisely define the nature of this fuel, which makes difficult the development of valorization processes. In an attempt of clarification, a classification was established by a French professional organization of recycling companies (FEDEREC). SRFs are classified into four classes depending on the standards defined for the following parameters: lower heating value; density; particle size; halogen compounds concentration; sulfur, nitrogen and ash contents. A better definition of SRF is expected to facilitate the development of specific valorization routes having better energy efficiency than the actual use of SRF as fuel in cement kiln.

Gasification consists of a partial oxidation of the solid fuel at high temperature $\left(800-1000{ }^{\circ} \mathrm{C}\right)$ using an oxidizing agent (air, steam, $\mathrm{O}_{2}$ or $\mathrm{CO}_{2}$ ). The solid fuel is mainly decomposed into syngas, a mixture of partially oxidized species $\left(\mathrm{H}_{2}, \mathrm{CO}, \mathrm{CO}_{2}, \mathrm{CH}_{4}, \mathrm{C}_{\mathrm{n}} \mathrm{H}_{\mathrm{m}}\right)$ having high calorific value. Gasification process has been intensively investigated for biomass valorization, but the presence of pollutants in the syngas (such as tar, acid gases, and particulate matter) compromises its valorization [6].

Different gasification technologies have been developed. Among them, fluidized bed reactor appears as the most suitable for medium-size processes (1 to $100 \mathrm{MW}$ ), due to the efficient flow mixing between reactants, the carefully controlled temperature, the high heat transfer performance, and the large operating flexibility allowing to use different kinds of fuels, including biomass and solid wastes [7-9]. 
Air-blown bubbling fluidized bed was proved to efficiently convert different wastes in syngas: meat waste and wastewater treatment sludge [10,11], tires [12,13], poultry fuel [14], plastic wastes [15,16], municipal solid waste [17,18], biomass waste [19,20], and solid recovered fuels [21,22]. Olivine, dolomite, and sand are the most frequently used bed materials in fluidized bed reactor. Sand can be used as bed material to ensure the fluidization, but has insignificant catalytic activity in tar cracking reaction. To improve the gasification efficiency and the syngas quality, catalysts can be used as bed materials. Dolomite is the low-cost catalyst having the highest catalytic activity in tar reforming reactions [22]. Dolomite can also prevent bed agglomeration when the fuel gasified is rich in alkaline and alkaline earth metals [23]. The main drawback of dolomite consists in its attrition tendency which significantly increases the dust pollution in syngas from fluidized bed. On the contrary, olivine presents strong mechanical properties despite relatively low catalytic activity in tar cracking reactions [22,24]. Olivine is often used as bed material in fluidized bed reactors, which reduces the dust load in syngas, and slightly decreases the tar content. Other types of materials have been tested, and their pros and cons are reported in the comprehensive review of Shen et al. [25].

At industrial scale, the gasifiers are autothermal, but it is not the case at lab-scale because the walls of small reactors must be heated to balance the heat loss. As a consequence, temperature and ER are independent conditions, whereas temperature depends on ER at industrial scale. In the past few years, SRFs gasification was increasingly studied in lab-scale fluidized beds, and the effect of the operating conditions on gasification behavior was investigated. Increasing equivalence ratio (ER) was proved to promote the oxidation reactions which increases both the syngas yield and the carbon conversion [26,27]. Similar results were obtained with the gasification of other wastes [10,28]. Oxidation reactions decreased the content of $\mathrm{H}_{2}, \mathrm{CO}, \mathrm{CH}_{4}$ and light hydrocarbon compounds [29-31], resulting in a drop of the syngas LHV and of the CGE. The influence of the temperature has also been investigated. Rising gasification temperature at a fixed ER value increases the syngas yield and carbon conversion [28]. Globally, the cold gas efficiency (CGE) decreased with increasing temperatures due to the drop in syngas LHV [26,27]. Contradictory results were reported about the evolution of the $\mathrm{CH}_{4}$ content and of the LHV of the syngas. While Berrueco et al. found that they reached a maximum at $800{ }^{\circ} \mathrm{C}$ before to decrease with higher temperature [26,27], Dunnu et al. reported that they increased with rising temperature from 800 to $850{ }^{\circ} \mathrm{C}$ [21]. These opposite trends can result from the different SRF composition, but a lack of study devoted to the influence of the SRF composition prevents to conclude this point.

Most of the already published articles mainly focused on "synthetic" SRF consisting in the mixture of well-known plastics and biomass, without taking into consideration the complexity of a real SRF composition. In the present paper, two industrial SRFs having different chemical compositions have been used to improve the understanding of the SRFs composition influence on the gasification efficiency. A detailed characterization of SRFs was performed. Gasification temperature and 
equivalence ratio (ER) have been sequentially varied in order to identify their separate contribution on the gasification efficiency. The syngas composition was measured on-line with a $\mu$-GC allowing to analyze permanent gases and BTX. Gasification efficiency was analyzed based on four indicators: cold gas efficiency (CGE), carbon conversion (CC), syngas lower heating value ( $\mathrm{LHV}_{\text {syngas }}$ ), and the syngas yield $\left(\eta_{\text {syngas }}\right)$. The distribution of hydrogen and carbon atoms in the gaseous products was determined and discussed based on SRF composition and gasification conditions.

\section{Materials and methods}

\subsection{Characterization of the Solid Recovered Fuels}

The two SRFs samples were provided by different French companies. The elemental composition was measured according to the standard NF EN 15407. The ash content was measured at $550^{\circ} \mathrm{C}$ according to the standard NF EN 15403. The composition of the resulting ashes was measured by X-Ray Fluorescence Spectroscopy. This technique was chosen to cope with the problem of the silica mineralization required for ICP analysis. The $\mathrm{Br}, \mathrm{Cl}$, and $\mathrm{F}$ contents were specifically determined by ionic chromatography according to the standards NF EN 15408 and NF EN ISO 10304-1. The Lower Heating Value (LHV) of the SRF was measured with a calorimetric bomb (NF EN 15400). The proportion and composition of biomass, non-biomass, and inert materials were determined according to the French standard NF EN 15440.

\subsection{Gasification reactor}

Gasification tests were performed in a bubbling fluidized-bed constructed in our laboratory and presented in a previous article [32]. The gasifier is divided into three zones: the plenum $(\mathrm{d}=100 \mathrm{~mm}$, $\mathrm{H}=300 \mathrm{~mm})$, the bed zone $(\mathrm{d}=100 \mathrm{~mm}, \mathrm{H}=800 \mathrm{~mm})$, and the freeboard zone $(\mathrm{d}=140 \mathrm{~mm}, \mathrm{H}=800 \mathrm{~mm})$ (Figure 1). The gasifying agent was air whose flowrate was controlled by a mass flow controller (Brooks 5850S). At the bottom of the gasifier, a $3 \mathrm{~mm}$ thick inox grid was used as distributor plate to homogenize the air flow and insure an efficient fluidization. The gasifier is heated by eight electrical heater shells at a maximum temperature of $1000{ }^{\circ} \mathrm{C}$.

SRFs were fed at the top of the reactor with a sloping screw. Around $3 \mathrm{~kg}$ of olivine was placed in the gasifier. The particle size distribution of this olivine is presented in Figure S.1 (in Supplementary Material). At $800^{\circ} \mathrm{C}$, the minimum fluidization velocity ( $\mathrm{U}_{\mathrm{mf}}$ ) was measured at $0.15 \mathrm{~m} / \mathrm{s}$ at $800{ }^{\circ} \mathrm{C}$ in the reactor by progressively increasing the air flowrate while measuring the pressure drop in the gasifier. At the gasifier outlet, the syngas flowed through a cyclone to remove particles, before to be cooled with two air heat exchangers. A water Venturi scrubber was also used to remove tar and acid gases before flaring the syngas. The gasifier is equipped with 19 lateral tubes allowing to locally measure the bed and freeboard temperatures. Pressure was continuously measured below the grid and at the top of the freeboard zone. The syngas was sampled before the Venturi scrubber (see Figure 1) and analyzed on- 
line by a $\mu$-GC (Varian micro-GC 490) every 3 minutes. Permanent gases $\mathrm{N}_{2}, \mathrm{CO}, \mathrm{CO}_{2}, \mathrm{H}_{2}, \mathrm{CH}_{4}, \mathrm{C}_{2} \mathrm{H}_{2}$, $\mathrm{C}_{2} \mathrm{H}_{4}, \mathrm{C}_{2} \mathrm{H}_{6}, \mathrm{C}_{3} \mathrm{H}_{4}, \mathrm{C}_{3} \mathrm{H}_{6}$, and $\mathrm{C}_{6} \mathrm{H}_{6}$ were quantified with this technique.

At the end of the experiment, the bed material (olivine+ash+char) was recovered after being cooled under a pure $\mathrm{N}_{2}$ sweep gas. Its velocity was lower than the minimum fluidization velocity to avoid the mixing of the bed. A solid sampler was introduced through the top of the gasifier and its vertical position was set. This system allowed sampling $100 \mathrm{~mm}$ thick bed layers.

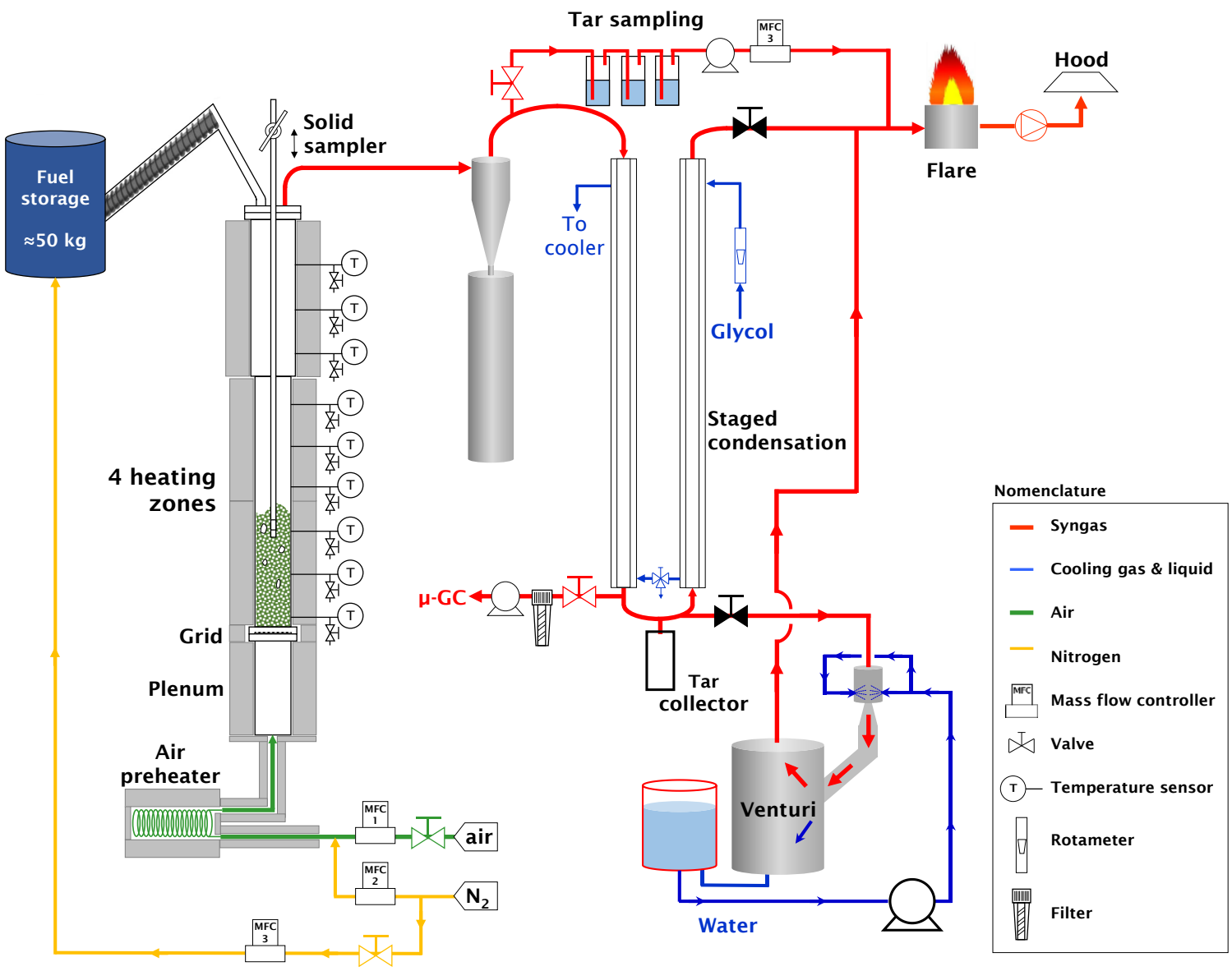

Figure 1: Scheme of the gasification device.

2.3 Gasification conditions

147 Before starting the gasification tests, the system was preheated at the desired temperature $\left(750-900{ }^{\circ} \mathrm{C}\right)$ under air. When the temperature was close to the gasification temperature, the air flowrate was set at the desired value. The air velocity was 4 times the minimum fluidization velocity, corresponding to an air flowrate of $4.5 \mathrm{~m}^{3} / \mathrm{h}(\mathrm{STP})$. Once the temperatures were stable along the gasifier, the gasification started by feeding the SRF at a controlled flowrate, corresponding to the desired ER. When the gasification conditions were stable (gasifier temperature, and syngas composition analyzed by $\mu$-GC), the permanent regime was maintained at least 40 minutes before to be modified (Figure 2). 


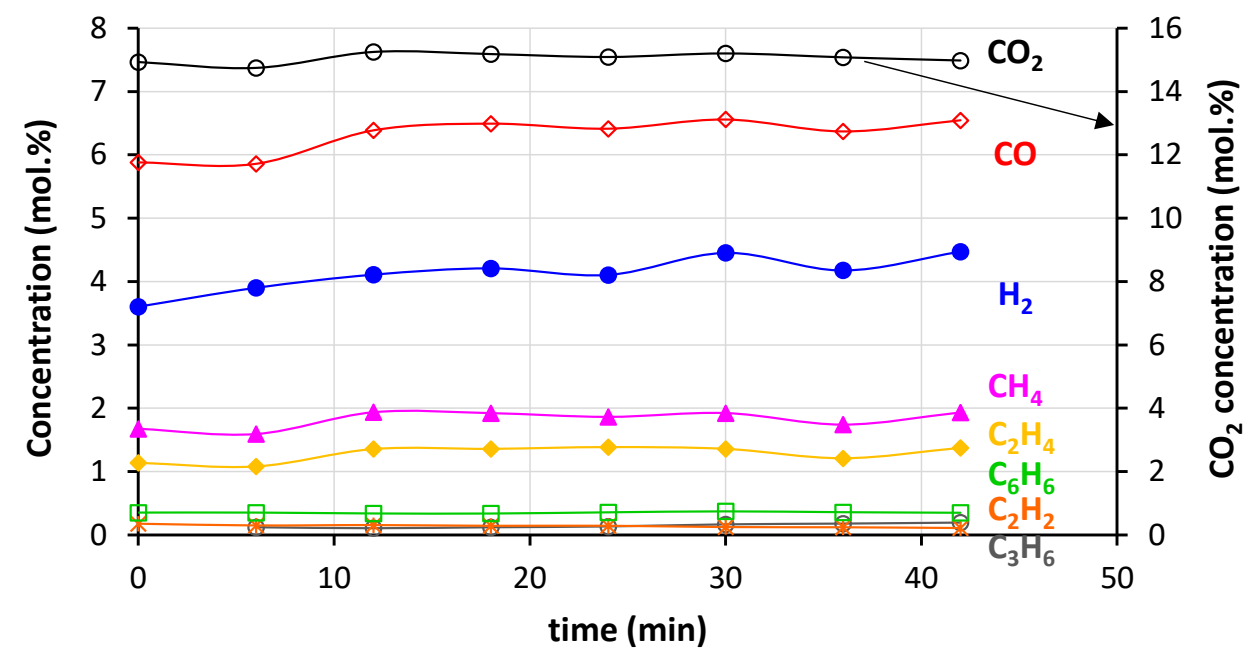

154

Figure 2: Example of permanent regime reached during the gasification of SRF1 at $800{ }^{\circ} \mathrm{C}$ with $E R=0.30$.

During the tests, either the temperature or the equivalence ratio (ER) was changed. ER is defined as the operating air flowrate divided by the air flowrate required for the stoichiometric SRF oxidation. In this study, the ER was varied between 0.21 and 0.35 . The SRF tank was continuously flushed with 10 $\mathrm{NL} / \mathrm{min}$ of pure $\mathrm{N}_{2}$ to avoid the degradation of the fuel in the feeding screw. This flowrate was taken into consideration for the results analysis by using $\mathrm{N}_{2}$ as a tracer for the calculation of the syngas flowrate.

\subsection{Evaluation of the gasification performance}

The gasification efficiency is mainly evaluated based on four indicators calculated from experimental results. As benzene is not a problematic compound for syngas valorization in gas engine [33], it is taken into account in these calculations. The lower heating value of the dry syngas ( $\left.\mathrm{LHV}_{\text {syngas }}\right)$ is calculated from a weighted average of the molar LHV of each gas (including benzene) and is expressed in $\mathrm{MJ} / \mathrm{m}^{3}$ (STP) of syngas (including $\mathrm{N}_{2}$ ), according to Eq.1:

$$
\operatorname{LHV}_{\text {syngas }}=\frac{\sum_{i}\left(\frac{\mathrm{LHV}_{\mathrm{i}}}{\mathrm{x}_{\mathrm{i}}}\right)}{\mathrm{V}_{\mathrm{m}}}
$$

Eq.1

Where $\mathrm{V}_{\mathrm{m}}$ represents the molar volume of ideal gas at STP $(22.4 \mathrm{~L} / \mathrm{mol})$, and $\mathrm{x}_{\mathrm{i}}$ the molar fraction of the gas species $i$.

The syngas yield ( $\eta_{\text {syngas }}$ ) corresponds to the volume of dry syngas produced (including $\mathrm{N}_{2}$ ) by $\mathrm{kg}$ of SRF (on dry ash free basis), and was calculated according to Eq.2:

$$
\eta_{\text {syngas }}=\frac{\mathrm{Qv}_{\text {syngas }}}{\mathrm{Qm}_{\mathrm{SRF}}}
$$

Where $Q v_{\text {syngas }}$ is the volumetric syngas flowrate including $\mathrm{N}_{2}\left(\mathrm{~m}^{3} / \mathrm{h} \mathrm{STP}\right)$ which is calculated using $\mathrm{N}_{2}$ as a tracer, and $\mathrm{Qm}_{\mathrm{SRF}}$ the mass flowrate of $\mathrm{SRF}\left(\mathrm{kg}_{\text {dat }} / \mathrm{h}\right)$. 
177 The carbon conversion (CC) expresses the percentage of carbon transferred from SRF to syngas, and is 178 calculated by Eq.3:

$$
C C=\mathrm{Qm}_{\text {syngas }} * M_{C} * \frac{\sum_{i}\left(\frac{X_{i}}{M_{i}} * n_{i}^{C}\right)}{Q m_{S R F} * X_{C}^{S R F}} * 100
$$

Where $\mathrm{Qm}_{\text {syngas }}$ is the mass flowrate of syngas $(\mathrm{kg} / \mathrm{h}), \mathrm{M}_{\mathrm{C}}$ is the molecular weight of carbon, $n_{i}^{C}$ is the number of carbon atoms in the molecule i, $X_{C}^{S R F}$ is the mass fraction of carbon is SRF (on daf basis), and $X_{i}$ and $M_{i}$ are respectively the mass fraction of the gas $i$ in the syngas and its molecular weight.

Finally, the last indicator is the Cold Gas Efficiency (CGE), expressed in \%, reflecting the fraction of chemical energy transferred from SRF to syngas:

$$
\mathrm{CGE}=\frac{\eta_{\text {syngas }} * \mathrm{LHV}_{\text {syngas }}}{\mathrm{LHV}_{\mathrm{SRF}}} * 100
$$

Eq.4

\section{Results}

\subsection{Physico-chemical properties of the SRF}

The two SRF studied were provided by two French companies and produced from distinct waste separation facilities managing different pristine types of wastes. Therefore, they represent interesting and complementary materials having different compositions (Table 1). SRF1 is ash-rich (>35 wt.\%) and relatively poor in carbon $(\approx 36 \mathrm{wt} . \%)$. On the contrary, the SRF2 is rich in carbon (52.6 wt.\%) and contains relatively small amount of ash (18.5 wt.\%). The oxygen content is almost similar for the two SRF ( $\approx 20$ wt.\%). SRF2 has a significantly higher LHV than SRF1 (Table 1), resulting from the lower ash content of SRF2.

The ash composition of the SRF was analyzed after combustion by XRF (Table 1). The ashes of SRF2 have high $\mathrm{Ca}$ and $\mathrm{Si}$ contents (35 and 30 wt.\%, respectively). It can be noted that SRF1 and SRF2 present a significant concentration of $\mathrm{Al}$ (18.53 and $17.44 \mathrm{wt} . \%)$. SRF1 contains the highest amount of $\mathrm{Si}(40.51$ wt.\%). Its $\mathrm{CaO}$ content is significant (25.86 wt.\%) but remains lower than that of SRF2. The results also showed that the two SRF are $\mathrm{Br}$-free, but contain both $\mathrm{Cl}$ and $\mathrm{F}$ (Table 1). According to the French classification, SRF2 is in class 4 due to its significant $\mathrm{Cl}$ content, while SRF1 is in class 2.

Table 1: Elemental analysis, ash composition, and lower heating value of the SRF.

\begin{tabular}{lcl} 
& \multicolumn{1}{c}{ SRF1 } & SRF2 \\
\multicolumn{2}{l}{ Elemental analysis (dry wt.\%) } & \\
\hline $\mathrm{C}$ & 36.3 & 52.6 \\
$\mathrm{H}$ & 4.9 & 7.2 \\
$\mathrm{~N}$ & 1.4 & 1.3 \\
$\mathrm{~S}$ & 0.3 & 0.2 \\
$\mathrm{O}$ & 20.0 & 20.3 \\
Ash & 37.1 & 18.5 \\
\hline
\end{tabular}




\begin{tabular}{lll}
\hline \multicolumn{3}{l}{ Ash composition (wt.\%) } \\
\hline $\mathrm{SiO}_{2}$ & 40.51 & 29.75 \\
$\mathrm{Al}_{2} \mathrm{O}_{3}$ & 17.44 & 18.53 \\
$\mathrm{Fe}_{2} \mathrm{O}_{3}$ & 4.94 & 5.52 \\
$\mathrm{TiO}_{2}$ & 1.14 & 2.19 \\
$\mathrm{CaO}$ & 25.86 & 34.65 \\
$\mathrm{MgO}$ & 4.78 & 2.42 \\
$\mathrm{Na} 2$ & 1.28 & 3.82 \\
$\mathrm{~K}_{2} \mathrm{O}$ & 1.15 & 0.76 \\
$\mathrm{SO}_{3}$ & 0.44 & 0.70 \\
$\mathrm{P}_{2} \mathrm{O}_{5}$ & 2.24 & 1.43 \\
$\mathrm{MnO}_{2}$ & 0.16 & 0.10 \\
$\mathrm{SrO}_{\mathrm{Total}}$ & 0.06 & 0.11 \\
$\mathrm{Br}, \mathbf{C l}$, and F contents (wt.\%) \\
\hline $\mathrm{Br}$ & 100.0 & 100.0 \\
$\mathrm{Cl}$ & 0.39 & 1.16 \\
$\mathrm{~F}$ & 0.02 & 0.01 \\
\hline LHV (MJ/kg dry $)$ & \\
\hline \multicolumn{4}{l}{} \\
\hline & 14.3 & 22.4 \\
\hline
\end{tabular}

203 Table 2 presents the proportion and composition of biomass, non-biomass, and inert materials 204 composing the two SRFs. SRF1 contains the higher fractions of inert and biomass materials (10.6 and 55.2 wt.\%, respectively). Its biomass fraction mainly consists in fines and paper/cartons, while glass roughly composes the inert fraction. This latter explains its significant $\mathrm{SiO}_{2}$ content measured by XRF.

207 The SRF2 mainly consists in non-biomass materials (Table 2) predominantly composed of plastics. Indeed, plastics represent 65 wt.\% of SRF2. SRF2 was inert-free, and its biomass fraction was composed of textiles, paper/cartons, and wood. These characterizations demonstrate that the two selected SRFs have significantly different compositions.

Table 2: Proportion and composition of biomass, non-biomass, and inert materials in the SRF.

\begin{tabular}{|r|c|c|}
\cline { 2 - 3 } \multicolumn{1}{c|}{} & \multicolumn{1}{c|}{ SRF1 } & SRF2 \\
\hline Biomass fraction (wt.\% dry) & $\mathbf{5 5 . 2}$ & $\mathbf{2 7 . 8}$ \\
\hline paper/carton & 44.9 & 29.3 \\
\hline wood & 1.3 & 16.3 \\
\hline textiles & 0.0 & 30.0 \\
\hline fines $<10 \mathrm{~mm}$ & 53.8 & 24.4 \\
\hline Non-biomass fraction (wt.\% dry) & $\mathbf{3 4 . 3}$ & $\mathbf{7 2 . 4}$ \\
\hline plastics & 13.3 & 90.7 \\
\hline carpet/matress & 0.0 & 0.0 \\
\hline fines $<10 \mathrm{~mm}$ & 86.4 & 9.3 \\
\hline Inert fraction (wt.\% dry) & $\mathbf{1 0 . 6}$ & $\mathbf{0 . 0}$ \\
\hline ferrous metals & 0.0 & 0.0 \\
\hline non-ferrous metals & 0.0 & 0.0 \\
\hline rocks & 13.8 & 0.0 \\
\hline glass & 86.2 & 0.0 \\
\hline
\end{tabular}




\section{$213 \quad 3.2 .1$ Influence of the Equivalence Ratio}

214 To study the separate influence of the Equivalence Ratio (ER) on the gasification efficiency, 215 the SRFs were gasified at a temperature of $810-825{ }^{\circ} \mathrm{C}$ controlled by the electrical heater shells. The 216 ER was adjusted from 0.21 to 0.35 by modifying the SRF flowrate (between 2.3 and $5.9 \mathrm{~kg} / \mathrm{h}$ on dry basis) while keeping a constant air flowrate in order to maintain similar fluidization conditions.

The evolutions of the cold gas efficiency (CGE), carbon conversion (CC), syngas yield ( $\eta_{\text {syngas }}$ ), and lower heating value of the syngas ( $\mathrm{LHV}_{\text {syngas }}$ ) versus ER are presented in Figure 3. Whatever the SRF composition, it can be observed that increasing ER led to: (i) a slight decrease of the CGE; (ii) a significant increase in syngas yield; and (iii) a decrease of the $\mathrm{LHV}_{\text {syngas. }}$ These results are in agreement with previous studies $[18,30]$. However, the carbon conversion evolution depended on the SRF composition. In the range $0.21<\mathrm{ER}<0.35$, the CC increased by $6.8 \%$ for SRF1, while it decreased by $5.6 \%$ for SRF2. This difference can be attributed to the large amount of ash in SRF1 (35 wt.\%), especially to the inorganic species known for their catalytic activity in gasification reaction (such as $\mathrm{Ca}$, $\mathrm{Na}, \mathrm{K}$ or $\mathrm{Fe}$ ) [34], which could catalyze the carbonaceous matter conversion. In addition, the type of plastics presents in SRF significantly influence the carbon conversion. For example, interactions occurring during the co-gasification of black polycarbonate and polyethylene-terephthalate with biomass were found to increase the carbon conversion, while no interaction was observed with polypropylene [35]. Moreover, other interactions could occur between plastics and biomass to enhance the char yield by promoting secondary reactions (condensation, polymerization), which decrease the carbon conversion [36]. A precise analysis of the plastic fractions would be required to elucidate the evolution of carbon conversion. Part of the carbon initially contained in the SRF was present in tars and fly ash generated during the gasification test, which explains that the carbon conversion is lower than $100 \%$. 

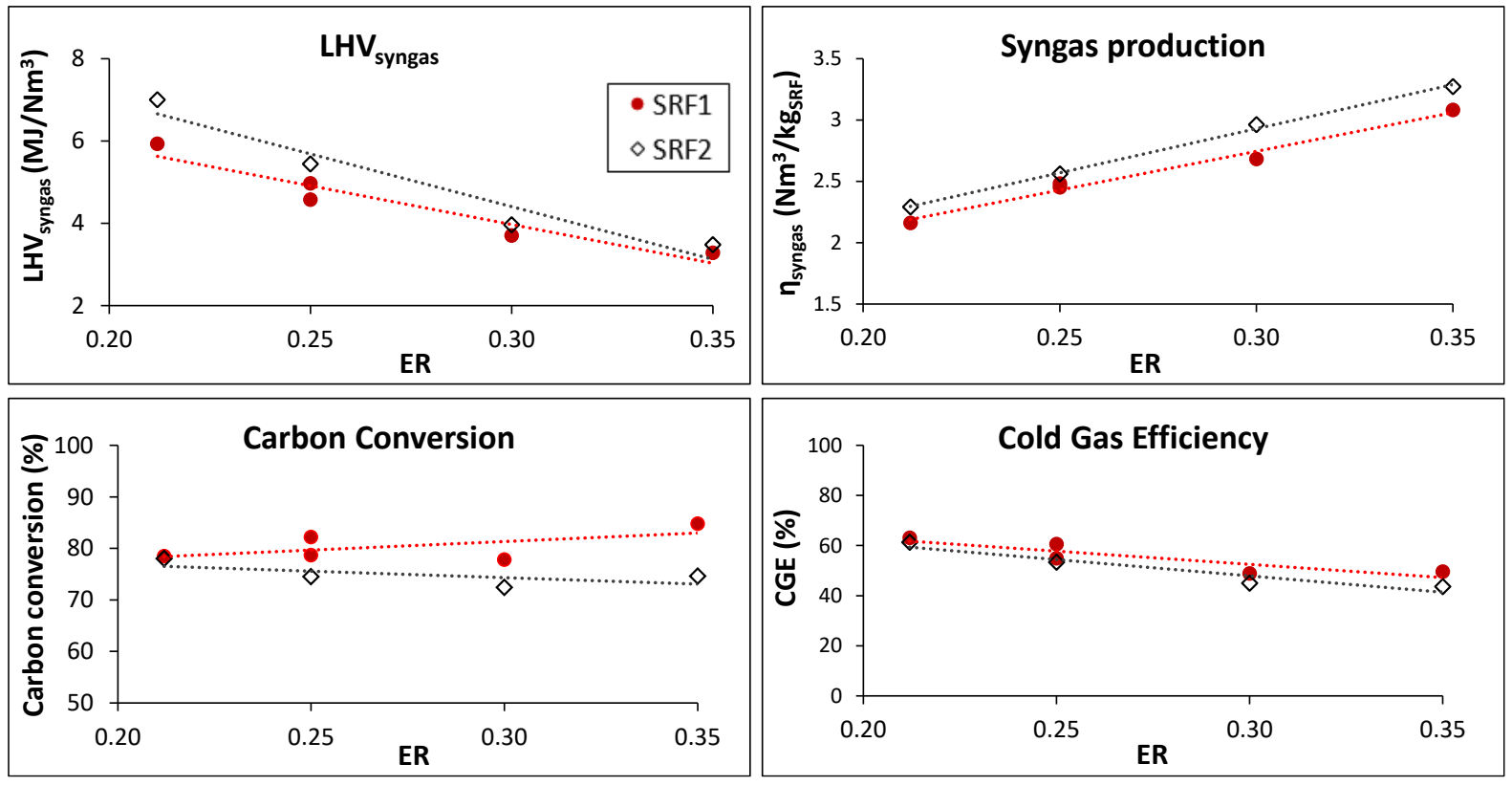

Figure 3: Evolution of the syngas Lower Heating Value ( $\left.L H V_{\text {syngas }}\right)$, the syngas production $\left(\eta_{\text {syngas }}\right)$, the carbon conversion (CC) and the Cold Gas Efficiency (CGE) with the ER at a temperature of 800-

The increase in syngas yield with rising ER is explained by the higher ratio of air to SRF in the gasifier.

If one subtracts the nitrogen from the outlet gas flowrate, the syngas yield (i.e. the gas produced) slightly increased with rising ER (Figure 4). However, it can be observed that the syngas production was around $20 \%$ higher with SRF1.

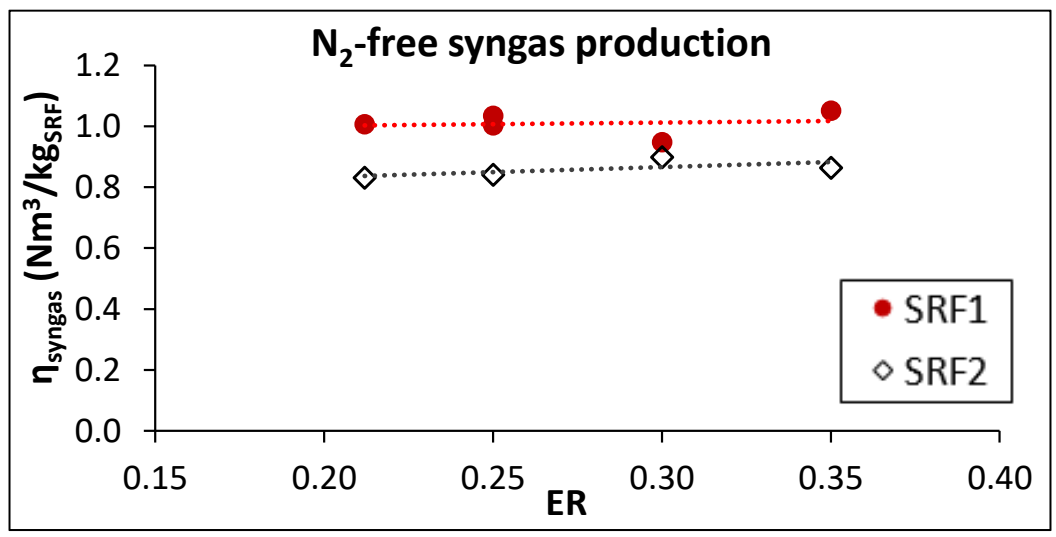

Figure 4: Evolution of the syngas yield free of nitrogen with ER.

To better understand the relationships between the SRF composition and the gasification phenomenon, the syngas composition was also studied. Table S.1 (in Supplementary Material) presents the syngas composition at the gasifier outlet, while Figure 5 displays the composition of the gas produced by gasification (nitrogen free). Rising ER decreased the fraction of the produced gases, except for $\mathrm{CO}_{2}$. This latter increased due to the syngas oxidation reactions promoted by increasing ER (R1): 
252 This reaction also contributed to the decrease of the $\mathrm{LHV}_{\text {syngas }}$ with increasing ER. Indeed, the LHV of 253 the $\mathrm{N}_{2}$-free syngas was proved to decrease with increasing ER (Figure 6). Plastic-rich SRF2 presented 254 higher LHV $_{\text {syngas }}$ than biomass-rich SRF1, which is in agreement with a previous study [15].
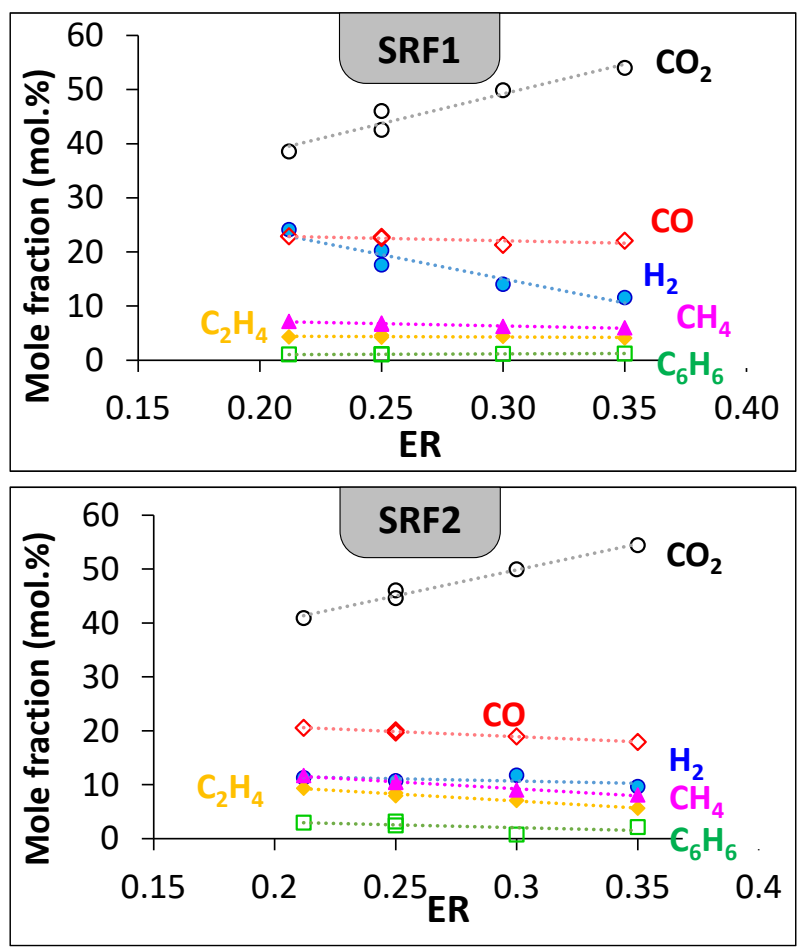

Figure 5: Evolution of the composition of the gas produced (without nitrogen) with ER for the different SRFs at a temperature of $800-820^{\circ} \mathrm{C}$.

For SRF2, $\mathrm{H}_{2}$ and $\mathrm{CH}_{4}$ display similar evolution and comparable concentration with rising ER (Figure 5). However, for SRF1, the $\mathrm{H}_{2}$ content was significantly higher than that of $\mathrm{CH}_{4}$, especially at low ER. The $\mathrm{H}_{2} / \mathrm{CH}_{4}$ ratio was equal to 3.4 at $\mathrm{ER}=0.21$, and to 1.9 at $\mathrm{ER}=0.35$.

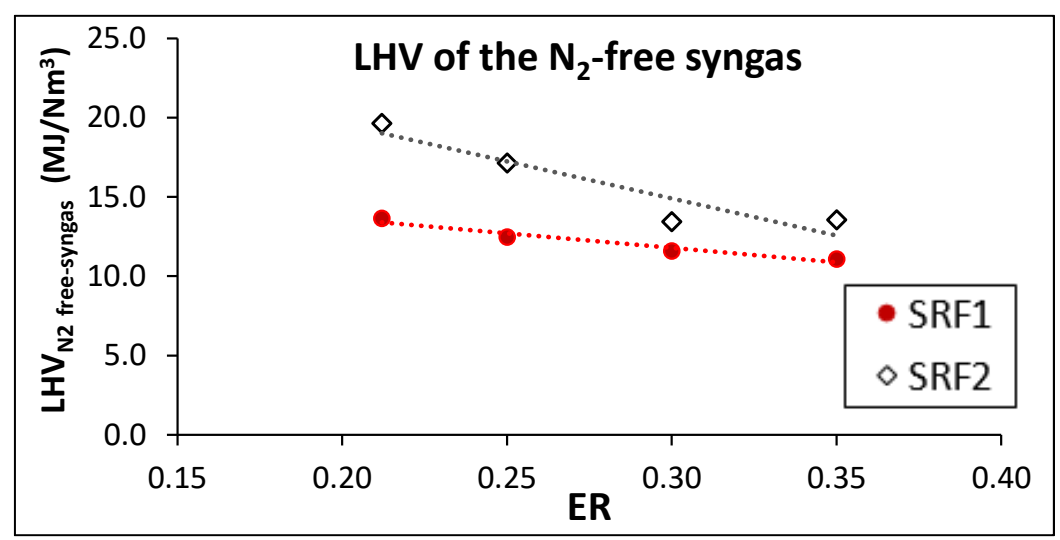

Figure 6: Evolution of the Lower Heating Value of the $N_{2}$-free syngas with (ER). 
To go further in the $\mathrm{H}$-species composition, the distribution of $\mathrm{H}$ atoms in the gaseous products was calculated, according to Eq.(5):

$$
\mathrm{S}_{H}^{i}=\frac{n_{H^{*} F^{i}}^{\sum_{k}\left(n_{H}^{k} * F^{k}\right)}}{\sum^{2}}
$$

267

Where $S_{H}^{i}$ is the molar selectivity representing the fraction of $\mathrm{H}$ atoms present in the syngas in the form of the molecule $i, n_{H}^{k}$ is the number of $\mathrm{H}$ atom in the molecule $k$, and $F^{k}$ is the molar flowrate of the gas $k$.
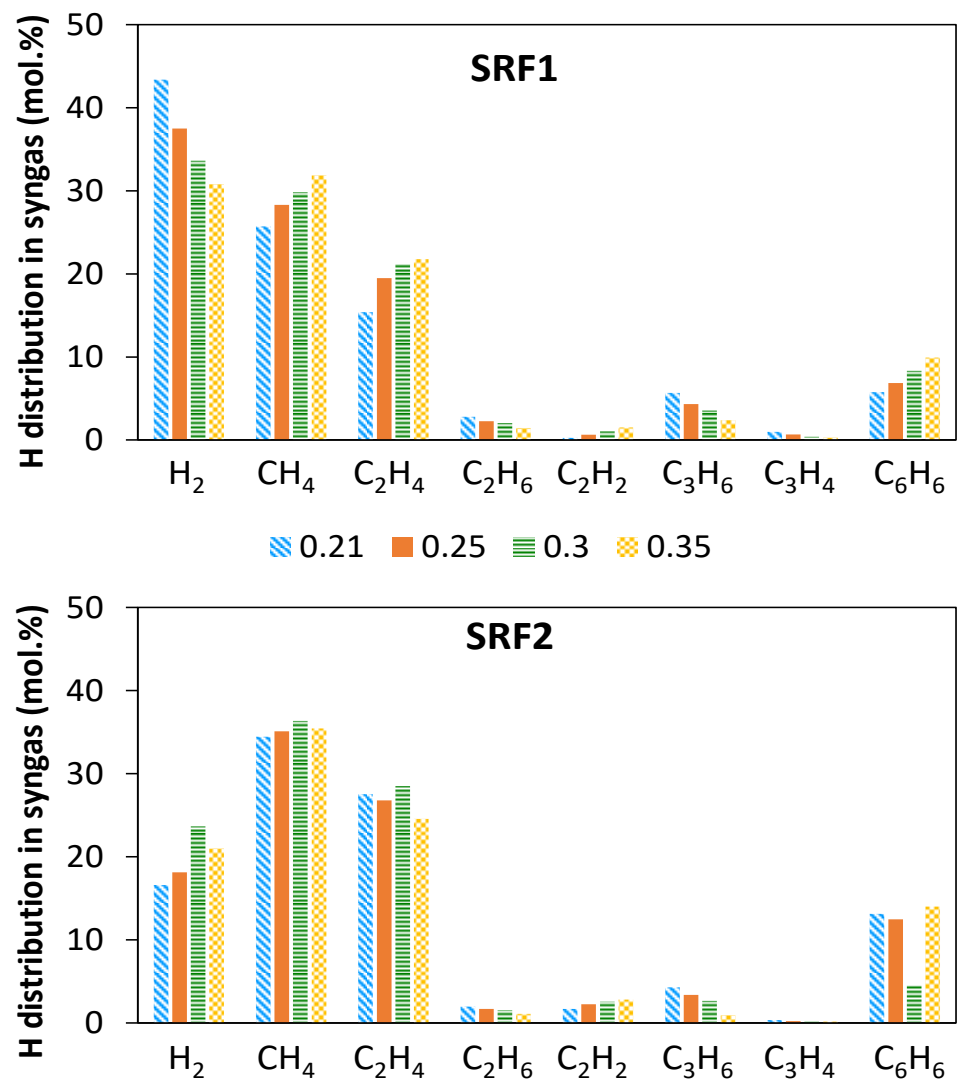

Figure 7: Molar distribution of hydrogen in H-containing gases depending on the ER at a temperature of $800-820^{\circ} \mathrm{C}$.

The results, presented in Figure 7, confirm that $\mathrm{H}_{2}$ was the main $\mathrm{H}$-containing gas produced during the gasification of SRF1, with a selectivity ranging between 31 and $43 \%$, followed by $\mathrm{CH}_{4}$ and $\mathrm{C}_{2} \mathrm{H}_{4}$. For SRF1, the selectivity in $\mathrm{H}_{2}, \mathrm{C}_{3} \mathrm{H}_{6}, \mathrm{C}_{2} \mathrm{H}_{6}$ and $\mathrm{C}_{3} \mathrm{H}_{4}$ decreased with rising ER, while that of $\mathrm{CH}_{4}, \mathrm{C}_{2} \mathrm{H}_{2}$, $\mathrm{C}_{2} \mathrm{H}_{4}$ and $\mathrm{C}_{6} \mathrm{H}_{6}$ displayed the reverse trend. For SRF2, the distribution of H-gaseous products was significantly different. Indeed, the main H-products were $\mathrm{CH}_{4}>\mathrm{C}_{2} \mathrm{H}_{4}>\mathrm{H}_{2}$. As SRF are very complex materials composed of a mixture of heterogeneous wastes, it is difficult to precisely discriminate the specific contribution of each component, or the interactions between each of them. However, based on the characterization performed and on the previous articles, these results tend to indicate that high plastic content in the SRF is likely responsible for the formation of stable light hydrocarbon species, 
while the $\mathrm{H}_{2}$ content in the syngas is low compared to syngas from biomass-rich SRF $[16,31,37]$. The significant content of $\mathrm{CH}_{4}$ and $\mathrm{C}_{2} \mathrm{H}_{4}$ in syngas from SRF2 results from the decomposition of the plastic polymer chains generating various types of hydrocarbon species. Contrary to the trend observed with SRF1, the selectivity in $\mathrm{H}_{2}$ did not decrease with rising ER for SRF2.

Similarly, the distribution of $\mathrm{C}$ atoms in the gaseous products was calculated (Figure 8). For SRF1, the two most important C-gases were $\mathrm{CO}_{2}$ (43-54 \%) and $\mathrm{CO}$ (22-26 \%), followed by $\mathrm{C}_{2} \mathrm{H}_{4}(8-10 \%)$. The selectivities in $\mathrm{CH}_{4}$ and $\mathrm{C}_{6} \mathrm{H}_{6}$ were comparable (6-8 \%) while that of other hydrocarbon species was lower than $3.6 \%$. The carbon distribution in syngas from SRF2 was slightly different. Although $\mathrm{CO}_{2}$ and $\mathrm{CO}$ were also the main products, their selectivities were significantly lower (35-50\%, and 16-19 $\%$, respectively). On the contrary, the selectivity in $\mathrm{C}_{2} \mathrm{H}_{4}, \mathrm{CH}_{4}, \mathrm{C}_{6} \mathrm{H}_{6}$, and $\mathrm{C}_{2} \mathrm{H}_{2}$ was substantially higher than that obtained with SRF1. These results confirm that SRFs having high plastic content generate syngas rich in hydrocarbon compared to syngas from biomass-rich SRF. Moreover, these results revealed that syngas oxidation reactions were promoted by rising ER, since the distribution of carbon atoms in syngas in the form of $\mathrm{CO}_{2}$ increased from 43 to $54 \%$ for SRF1, and from 35 to $50 \%$ for SRF2.
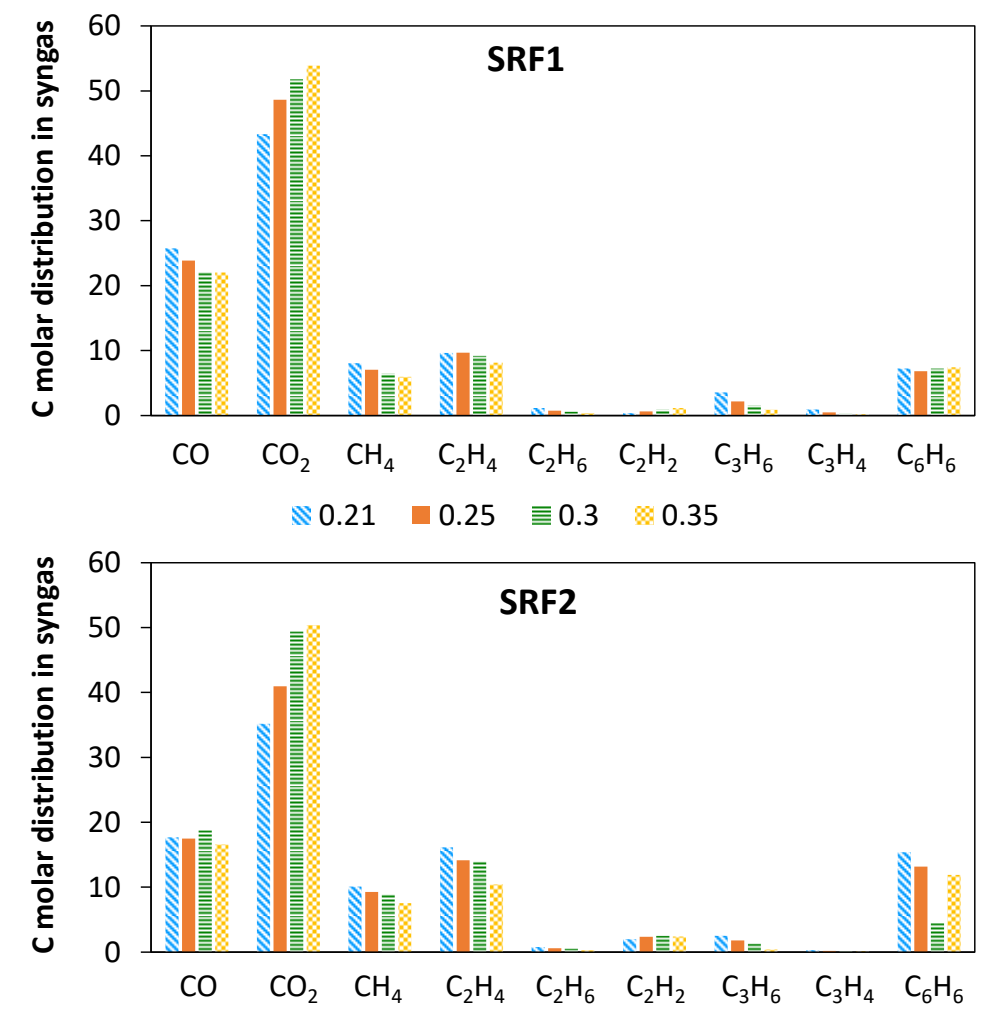

\section{Figure 8: Molar distribution of carbon in C-containing gases depending on the ER at a temperature of $800-820^{\circ} \mathrm{C}$.}

\subsubsection{Influence of the Temperature}

The separate influence of the temperature on the gasification efficiency was investigated by gasifying the SRFs at constant ER (0.25) while varying the reactor temperature between 750 and $905^{\circ} \mathrm{C}$. 
The evolution of the cold gas efficiency (CGE), the carbon conversion (CC), the syngas yield $\left(\eta_{\text {syngas }}\right)$ and the lower heating value of the syngas $\left(\operatorname{LHV}_{\text {syngas }}\right)$ versus gasification temperature is presented in Figure 9. For the two SRFs, increasing temperature resulted in the enhancement of the gasification efficiency, as reflected by the increase in $\mathrm{LHV}_{\text {syngas, }}$ syngas production, CGE and CC. However, a problem of ash melting was encountered during the gasification of SRF1 at $880{ }^{\circ} \mathrm{C}$, leading to the defluidization and the agglomeration of the bed. The agglomerate formed is presented in Figure 10. The results of this test are not presented, as the experiment had to be stopped before to reach the steady state. This agglomeration phenomenon was not observed during the high temperature tests with the SRF2. The high content of Si and P in the SRF1 ashes (40.51 and $2.24 \mathrm{wt} \%$, respectively) could contribute to this behavior, as these species are known to melt under gasification conditions $[34,38,39]$.
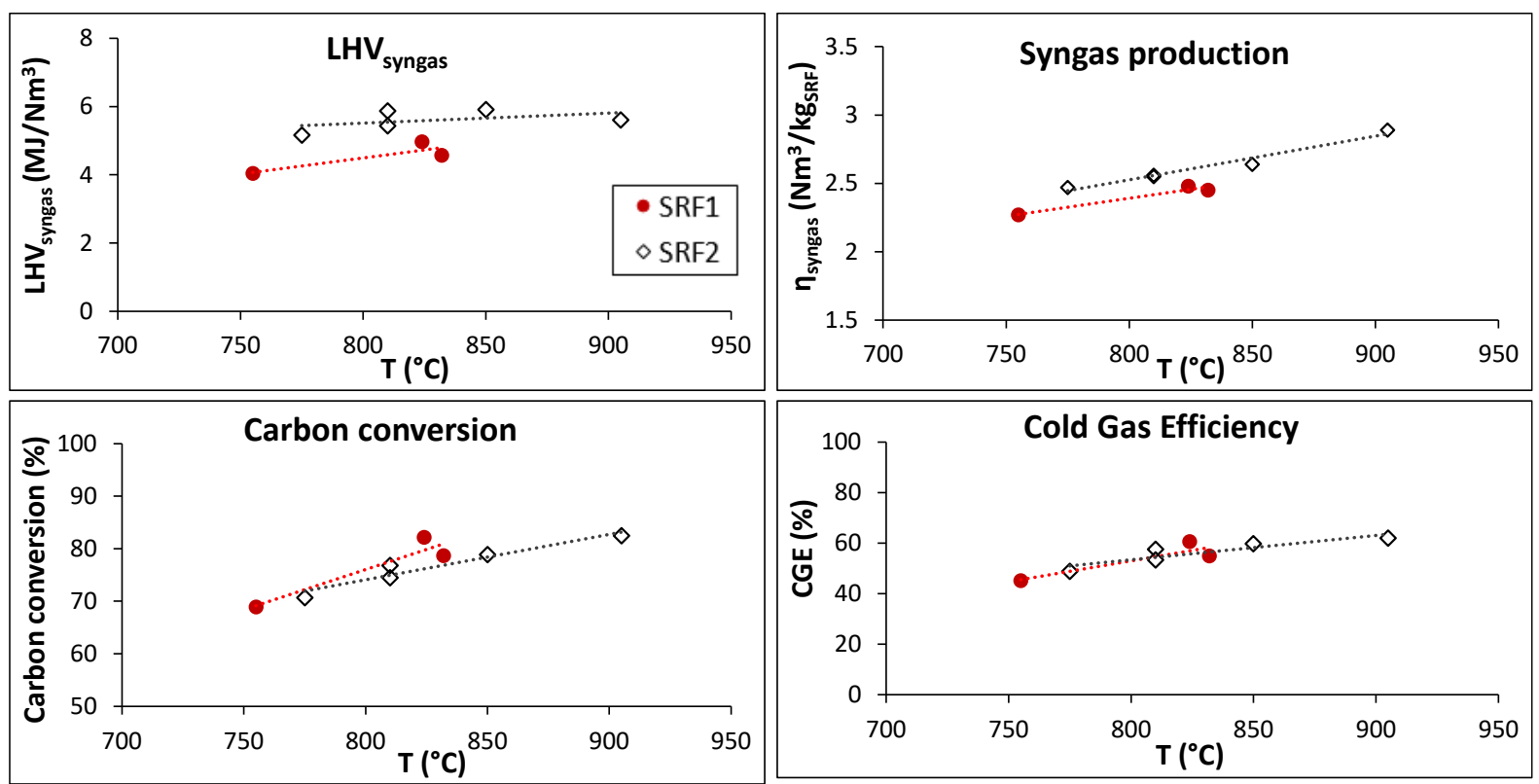

Figure 9: Evolution of Cold Gas Efficiency (CGE), carbon conversion (CC), syngas yield, and syngas lower heating value versus gasification temperature. 


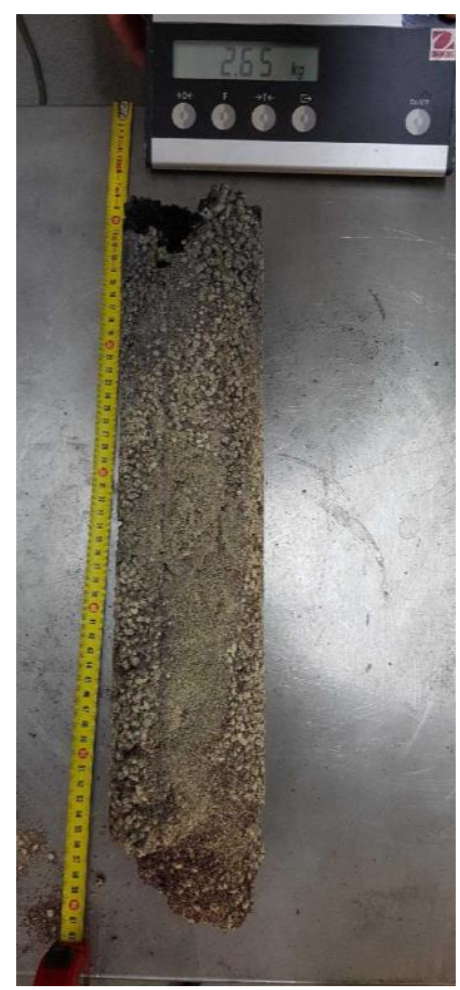

Figure 10: Picture of the agglomerate formed in the olivine bed during the gasification of SRF1 at

318 To go further in the understanding of the relationships between the SRF composition and the gasification phenomenon, the syngas composition was also studied. Table S.2 (in Supplementary Material) presents syngas composition at the gasifier outlet, while Figure 11 displays the composition of the gas produced by gasification reactions (nitrogen free). Whatever the nature of the SRF, the CO and $\mathrm{H}_{2}$ contents increased with rising temperature (Figure 11). On the contrary, the $\mathrm{CO}_{2}$ content decreased at higher temperatures. These trends can be attributed to several phenomena. Indeed, high gasification temperature can promote: the kinetic of gasification reactions generating $\mathrm{H}_{2}$ and $\mathrm{CO}$ at the expense of $\mathrm{CO}_{2}(\mathrm{R} 2)$; steam and dry reforming reactions of tar and light hydrocarbons which consume $\mathrm{H}_{2} \mathrm{O}$ and $\mathrm{CO}_{2}$ to produce $\mathrm{H}_{2}$ and $\mathrm{CO}(\mathrm{R} 3$ and $\mathrm{R} 4)$; and tar cracking reactions, mainly generating $\mathrm{H}_{2}$ and $\mathrm{CO}[21,26,27]$. In addition to dry reforming reaction, the decrease in $\mathrm{CO}_{2}$ can also be attributed to Boudouard reaction (R5), and to the Reverse Water-Gas Shift Reaction (R6). All these reactions are expected to occur simultaneously, thus explaining the syngas composition as well as the increase in gasification efficiency with rising temperature.

$$
\mathrm{C}_{\mathrm{n}} \mathrm{H}_{\mathrm{m}}+\frac{\mathrm{n}}{2} \mathrm{O}_{2} \rightarrow \mathrm{nCO}+\frac{\mathrm{m}}{2} \mathrm{H}_{2}
$$

$$
\mathrm{C}_{\mathrm{x}} \mathrm{H}_{\mathrm{y}}+\mathrm{xH}_{2} \mathrm{O} \rightarrow \mathrm{xCO}+\left(\mathrm{x}+\frac{\mathrm{y}}{2}\right) \mathrm{H}_{2}
$$

$$
\mathrm{C}_{\mathrm{x}} \mathrm{H}_{\mathrm{y}}+\mathrm{xCO}_{2} \rightarrow 2 \mathrm{xCO}+\frac{\mathrm{y}}{2} \mathrm{H}_{2}
$$



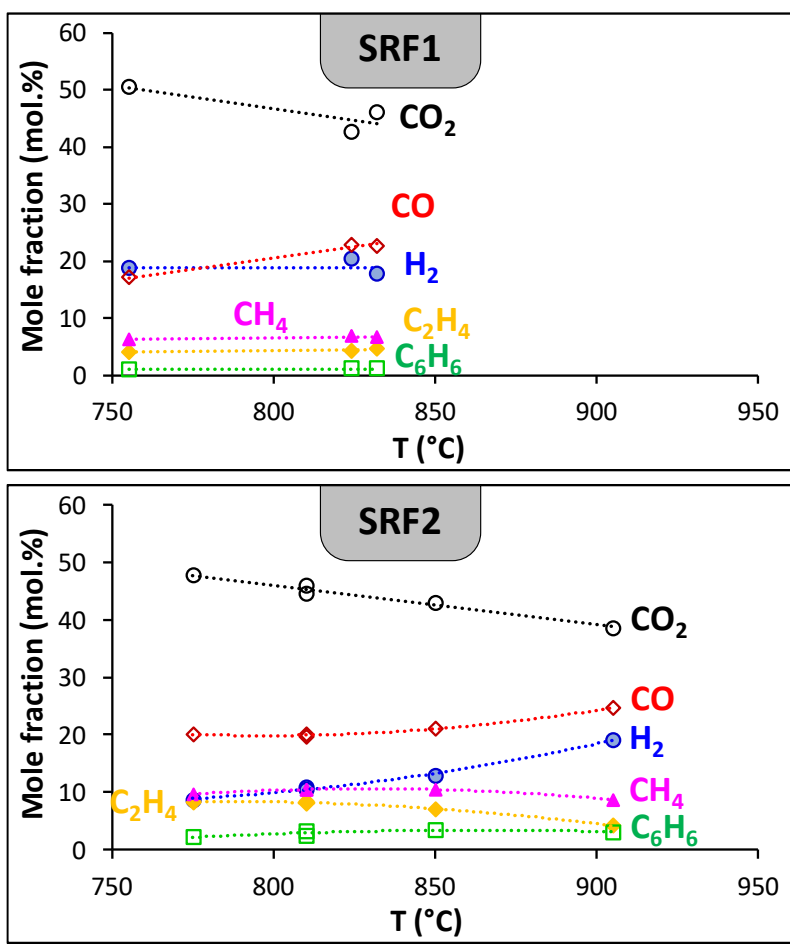

339 The influence of the temperature on the distribution of hydrogen atoms in the gaseous products is

340 presented in Figure 12. For the two SRFs, rising temperature increased the selectivity in $\mathrm{H}_{2}$, especially 341 at temperature higher than $850{ }^{\circ} \mathrm{C}$. This increase in $\mathrm{H}_{2}$ was also observed for the SRF2 rich in plastics.

342 Simultaneously, the selectivity in light hydrocarbons $\left(\mathrm{C}_{2} \mathrm{H}_{4}, \mathrm{C}_{2} \mathrm{H}_{6}, \mathrm{C}_{3} \mathrm{H}_{4}\right.$, and $\left.\mathrm{C}_{3} \mathrm{H}_{6}\right)$ significantly decreased. These evolutions together with the drop of $\mathrm{CO}_{2}$ strengthen the hypothesis of dry reforming reactions. The reduction of light hydrocarbon species counterbalances the increase of $\mathrm{H}_{2}$ and $\mathrm{CO}$ : as a result, the $\mathrm{LHV}_{\text {syngas }}$ is relatively stable (Figure 9). In addition, tar reforming reactions are known to be promoted by high temperature $[26,27]$ which can also explain the increase in $\mathrm{H}_{2}$ and benzene (which is

347 a product of light aromatics reforming) [40]. 

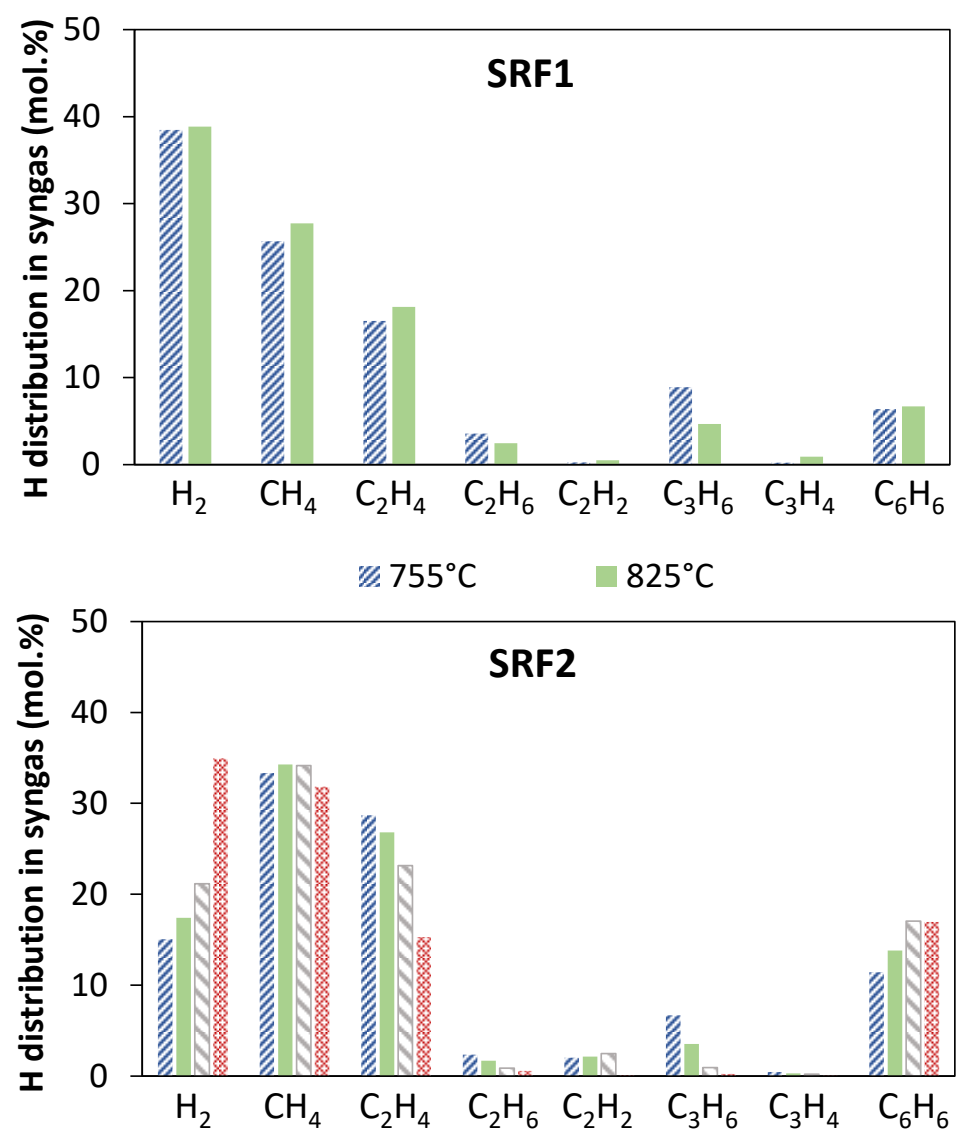

Figure 12: Distribution of hydrogen in H-containing gases depending on the gasification temperature.

\section{Conclusion}

This article studied the influence of the Solid Recovered Fuels (SRFs) composition and of the operating conditions on the gasification efficiency. Two industrial SRFs having different compositions were investigated. The gasification tests were performed at lab-scale in a bubbling fluidized bed using olivine as bed material, and air as gasifying agent. At industrial scale, the gasifiers are autothermal, but it is not the case at lab-scale because the wall of the small reactors must be heated to balance the heat loss. To better understand the gasification phenomena, the separate contribution of temperature and equivalence ratio (ER) on the gasification efficiency was investigated by sequentially varying these two parameters.

359 Gasification efficiency was analyzed based on the syngas quality and on four indicators: cold gas 360 efficiency (CGE), carbon conversion (CC), syngas lower heating value ( $\mathrm{LHV}_{\text {syngas }}$ ), and the syngas yield 361 ( $\left.\eta_{\text {syngas }}\right)$.

362 The SRFs characterization highlighted significant differences in terms of elemental and global composition. SRF1 was ash-rich $(\approx 37 \mathrm{wt} . \%)$ while its carbon content was relatively low ( $\approx 35 \mathrm{wt} . \%)$.

364 On the contrary, SRF2 was carbon-rich (53 wt.\%) and presented low ash content (18.5 wt.\%). The 
global composition showed that SRF1 was composed of a high biomass fraction (55.2 wt.\%) mainly consisting in paper/carton. On the contrary, SRF2 was mainly composed of plastics (65 wt.\%).

Gasification tests revealed that the $\mathrm{LHV}_{\text {syngas }}$ and the CGE significantly decreased with rising equivalence ratio (ER). This evolution resulted from the oxidation reactions promoted by high ER which decreased the concentration of carbonaceous gases at the expense of $\mathrm{CO}_{2}$, thus decreasing the $\mathrm{LHV}_{\text {syngas. }}$ The syngas yield was proved to be almost constant with increasing ER. For these reasons, the CGE decreased with rising ER. The significant amount of inorganic species (such as $\mathrm{Ca}, \mathrm{Na}, \mathrm{K}$ or $\mathrm{Fe}$ ) present in SRF1 was expected to catalyze the gasification reactions of the carbonaceous matter, thus explaining the higher carbon conversion of SRF1 over SRF2. In addition, synergistic effects between plastics and biomass in SRF2 could promote secondary reactions leading to char formation. The $\mathrm{H}$ atoms distribution in syngas demonstrated that high plastic content in the SRF2 was responsible for the formation of stable light hydrocarbon species, while the $\mathrm{H}_{2}$ content in the syngas is low compared to syngas from biomass-rich SRF1.

Increasing gasification temperature at constant ER strongly improved the gasification efficiency whatever the SRF composition. Indeed, CGE, carbon conversion, syngas production and $\mathrm{LHV}_{\text {syngas }}$ were significantly increased between 750 and $900^{\circ} \mathrm{C}$. The main limitation to the use of high temperature was the melting of mineral species leading to bed agglomeration and defluidization. However, this behavior was only observed with SRF1 which contained large amount of Si and P, both known for their melting tendency under gasification conditions. Rising temperature resulted in the increase of $\mathrm{H}_{2}$ and $\mathrm{CO}$ concentration in the syngas, while the concentration of $\mathrm{CO}_{2}$ and light hydrocarbons decreased. This evolution can be attributed to the several simultaneous reactions: gasification, steam and dry reforming, tar cracking, Boudouard, and Reverse Water-Gas Shift. This study provides original data on the influence of SRFs composition and operating conditions on the gasification efficiency and syngas composition.

\section{Acknowledgements}

The authors acknowledge the financial support of ADEME to the Terracotta project (1606C0013). The authors also thank the EDF Company, especially Emmanuel Thunin and Mathieu Insa for their support on material characterizations.

\section{References}

[1] Solid Waste Management, World Bank. (n.d.). http://www.worldbank.org/en/topic/urbandevelopment/brief/solid-waste-management (accessed March 6, 2018).

[2] Statistiques sur les déchets - Statistics Explained, (n.d.). http://ec.europa.eu/eurostat/statisticsexplained/index.php/Waste_statistics/fr (accessed August 21, 2018). 
[3] P.H. Brunner, L. Morf, H. Rechberger, VI.3 - Thermal waste treatment - a necessary element for sustainable waste management, in: I. Twardowska (Ed.), Waste Manag. Ser., Elsevier, 2004: pp. 783-806. doi:10.1016/S0713-2743(04)80033-3.

[4] A. Porteous, Why energy from waste incineration is an essential component of environmentally responsible waste management, Waste Manag. 25 (2005) 451-459. doi:10.1016/j.wasman.2005.02.008.

[5] U. Arena, Process and technological aspects of municipal solid waste gasification. A review, Waste Manag. 32 (2012) 625-639. doi:10.1016/j.wasman.2011.09.025.

[6] T.A. Milne, R.. Evans, N. Abatzoglou, Biomass Gasifier Tars: Their Nature, Formation and Conversion., National Renewable Energy Laboratory, 1998.

[7] A. Ramos, E. Monteiro, V. Silva, A. Rouboa, Co-gasification and recent developments on waste-to-energy conversion: A review, Renew. Sustain. Energy Rev. 81 (2018) 380-398. doi:10.1016/j.rser.2017.07.025.

[8] S.K. Sansaniwal, K. Pal, M.A. Rosen, S.K. Tyagi, Recent advances in the development of biomass gasification technology: A comprehensive review, Renew. Sustain. Energy Rev. 72 (2017) 363-384. doi:10.1016/j.rser.2017.01.038.

[9] N. Couto, V.B. Silva, C. Bispo, A. Rouboa, From laboratorial to pilot fluidized bed reactors: Analysis of the scale-up phenomenon, Energy Convers. Manag. 119 (2016) 177-186. doi:10.1016/j.enconman.2016.03.085.

[10] M. Campoy, A. Gómez-Barea, P. Ollero, S. Nilsson, Gasification of wastes in a pilot fluidized bed gasifier, Fuel Process. Technol. 121 (2014) 63-69. doi:10.1016/j.fuproc.2013.12.019.

[11] U. Lee, J. Dong, J.N. Chung, Experimental investigation of sewage sludge solid waste conversion to syngas using high temperature steam gasification, Energy Convers. Manag. 158 (2018) 430-436. doi:10.1016/j.enconman.2017.12.081.

[12] H. Karatas, H. Olgun, B. Engin, F. Akgun, Experimental results of gasification of waste tire with air in a bubbling fluidized bed gasifier, Fuel. 105 (2013) 566-571. doi:10.1016/j.fuel.2012.08.038.

[13] G. Xiao, M.-J. Ni, Y. Chi, K.-F. Cen, Low-temperature gasification of waste tire in a fluidized bed, Energy Convers. Manag. 49 (2008) 2078-2082. doi:10.1016/j.enconman.2008.02.016.

[14] F. Di Gregorio, D. Santoro, U. Arena, The effect of ash composition on gasification of poultry wastes in a fluidized bed reactor, Waste Manag. Res. 32 (2014) 323-330. doi:10.1177/0734242X14525821.

[15] M.L. Mastellone, L. Zaccariello, U. Arena, Co-gasification of coal, plastic waste and wood in a bubbling fluidized bed reactor, Fuel. 89 (2010) 2991-3000. doi:10.1016/j.fuel.2010.05.019.

[16] U. Arena, F. Di Gregorio, Energy generation by air gasification of two industrial plastic wastes in a pilot scale fluidized bed reactor, Energy. 68 (2014) 735-743. doi:10.1016/j.energy.2014.01.084.

[17] N.D. Couto, V.B. Silva, A. Rouboa, Assessment on steam gasification of municipal solid waste against biomass substrates, Energy Convers. Manag. 124 (2016) 92-103. doi:10.1016/j.enconman.2016.06.077.

[18] B. Hu, Q. Huang, A. Buekens, Y. Chi, J. Yan, Co-gasification of municipal solid waste with high alkali coal char in a three-stage gasifier, Energy Convers. Manag. 153 (2017) 473-481. doi:10.1016/j.enconman.2017.10.026.

[19] M.P. González-Vázquez, R. García, M.V. Gil, C. Pevida, F. Rubiera, Comparison of the gasification performance of multiple biomass types in a bubbling fluidized bed, Energy Convers. Manag. 176 (2018) 309-323. doi:10.1016/j.enconman.2018.09.020. 
[20] V. Silva, A. Rouboa, Combining a 2-D multiphase CFD model with a Response Surface Methodology to optimize the gasification of Portuguese biomasses, Energy Convers. Manag. 99 (2015) 28-40. doi:10.1016/j.enconman.2015.03.020.

[21] G. Dunnu, K.D. Panopoulos, S. Karellas, J. Maier, S. Touliou, G. Koufodimos, I. Boukis, E. Kakaras, The solid recovered fuel Stabilat ${ }^{\circledR}$ : Characteristics and fluidised bed gasification tests, Fuel. 93 (2012) 273-283. doi:10.1016/j.fuel.2011.08.061.

[22] F. Pinto, R.N. André, C. Carolino, M. Miranda, P. Abelha, D. Direito, N. Perdikaris, I. Boukis, Gasification improvement of a poor quality solid recovered fuel (SRF). Effect of using natural minerals and biomass wastes blends, Fuel. 117 (2014) 1034-1044. doi:10.1016/j.fuel.2013.10.015.

[23] J. Corella, J.M. Toledo, R. Padilla, Olivine or Dolomite as In-Bed Additive in Biomass Gasification with Air in a Fluidized Bed: Which Is Better?, Energy Fuels. 18 (2004) 713-720. doi:10.1021/ef0340918.

[24] L. Devi, K.J. Ptasinski, F.J.J.G. Janssen, S.V.B. van Paasen, P.C.A. Bergman, J.H.A. Kiel, Catalytic decomposition of biomass tars: use of dolomite and untreated olivine, Renew. Energy. 30 (2005) 565-587. doi:10.1016/j.renene.2004.07.014.

[25] Y. Shen, J. Wang, X. Ge, M. Chen, By-products recycling for syngas cleanup in biomass pyrolysis - An overview, Renew. Sustain. Energy Rev. 59 (2016) 1246-1268. doi:10.1016/j.rser.2016.01.077.

[26] J. Recari, C. Berrueco, S. Abelló, D. Montané, X. Farriol, Gasification of two solid recovered fuels (SRFs) in a lab-scale fluidized bed reactor: Influence of experimental conditions on process performance and release of $\mathrm{HCl}, \mathrm{H} 2 \mathrm{~S}, \mathrm{HCN}$ and $\mathrm{NH} 3$, Fuel Process. Technol. 142 (2016) 107-114. doi:10.1016/j.fuproc.2015.10.006.

[27] C. Berrueco, J. Recari, S. Abelló, X. Farriol, D. Montané, Experimental Investigation of Solid Recovered Fuel (SRF) Gasification: Effect of Temperature and Equivalence Ratio on Process Performance and Release of Minor Contaminants, Energy Fuels. 29 (2015) 7419-7427. doi:10.1021/acs.energyfuels.5b02032.

[28] U. Arena, F. Di Gregorio, Fluidized bed gasification of industrial solid recovered fuels, Waste Manag. 50 (2016) 86-92. doi:10.1016/j.wasman.2016.02.011.

[29] L. Devi, K.J. Ptasinski, F.J.J.G. Janssen, A review of the primary measures for tar elimination in biomass gasification processes, Biomass Bioenergy. 24 (2003) 125-140. doi:10.1016/S09619534(02)00102-2.

[30] U. Arena, L. Zaccariello, M.L. Mastellone, Fluidized bed gasification of waste-derived fuels, Waste Manag. 30 (2010) 1212-1219. doi:10.1016/j.wasman.2010.01.038.

[31] A. Gómez-Barea, P. Ollero, B. Leckner, Optimization of char and tar conversion in fluidized bed biomass gasifiers, Fuel. 103 (2013) 42-52. doi:10.1016/j.fuel.2011.04.042.

[32] G. Lardier, J. Kaknics, A. Dufour, R. Michel, B. Cluet, O. Authier, J. Poirier, G. Mauviel, Gas and Bed Axial Composition in a Bubbling Fluidized Bed Gasifier: Results with Miscanthus and Olivine, Energy Fuels. 30 (2016) 8316-8326. doi:10.1021/acs.energyfuels.6b01816.

[33] GE Jenbacher, Fuel gas quality, special gases, 2009.

[34] C. Dupont, S. Jacob, K.O. Marrakchy, C. Hognon, M. Grateau, F. Labalette, D. Da Silva Perez, How inorganic elements of biomass influence char steam gasification kinetics, Energy. 109 (2016) 430-435. doi:10.1016/j.energy.2016.04.094.

[35] K.G. Burra, A.K. Gupta, Synergistic effects in steam gasification of combined biomass and plastic waste mixtures, Appl. Energy. 211 (2018) 230-236. doi:10.1016/j.apenergy.2017.10.130.

[36] A. Ephraim, D. Pham Minh, D. Lebonnois, C. Peregrina, P. Sharrock, A. Nzihou, Co-pyrolysis of wood and plastics: Influence of plastic type and content on product yield, gas composition and quality, Fuel. 231 (2018) 110-117. doi:10.1016/j.fuel.2018.04.140. 
[37] U. Arena, F. Di Gregorio, Gasification of a solid recovered fuel in a pilot scale fluidized bed reactor, Fuel. 117 (2014) 528-536. doi:10.1016/j.fuel.2013.09.044.

[38] C. Hognon, C. Dupont, M. Grateau, F. Delrue, Comparison of steam gasification reactivity of algal and lignocellulosic biomass: Influence of inorganic elements, Bioresour. Technol. 164 (2014) 347-353. doi:10.1016/j.biortech.2014.04.111.

[39] A. Nzihou, B. Stanmore, The fate of heavy metals during combustion and gasification of contaminated biomass - A brief review, J. Hazard. Mater. 256-257 (2013) 56-66. doi:10.1016/j.jhazmat.2013.02.050.

[40] A. Dufour, P. Girods, E. Masson, Y. Rogaume, A. Zoulalian, Synthesis gas production by biomass pyrolysis: Effect of reactor temperature on product distribution, Int. J. Hydrog. Energy. 34 (2009) 1726-1734. doi:10.1016/j.ijhydene.2008.11.075. 
Table S.1: Syngas composition (in mol.\%) at the gasifier outlet depending on the SRF for different Equivalent Ratio at a temperature of $800-820^{\circ} \mathrm{C}$.

\begin{tabular}{|c|cccc|cccc|}
\hline SRF & \multicolumn{9}{c}{ SRF1 } \\
\hline $\mathbf{E R}$ & $\mathbf{0 . 2 1}$ & $\mathbf{0 . 2 5}$ & $\mathbf{0 . 3 0}$ & $\mathbf{0 . 3 5}$ & $\mathbf{0 . 2 1}$ & $\mathbf{0 . 2 5}$ & $\mathbf{0 . 3 0}$ & $\mathbf{0 . 3 5}$ \\
$\mathrm{H}_{2}$ & 9.92 & 6.70 & 4.25 & 3.20 & 4.00 & 3.31 & 3.43 & 2.46 \\
$\mathrm{O}_{2}$ & 0.00 & 0.08 & 0.53 & 0.00 & 0.14 & 0.04 & 0.14 & 0.11 \\
$\mathrm{CO}$ & 9.42 & 8.00 & 6.46 & 6.12 & 7.27 & 6.18 & 5.53 & 4.57 \\
$\mathrm{CO}_{2}$ & 15.85 & 15.60 & 15.13 & 14.98 & 14.46 & 14.08 & 14.57 & 13.87 \\
$\mathrm{C}_{2} \mathrm{H}_{4}$ & 1.76 & 1.55 & 1.34 & 1.13 & 3.31 & 2.55 & 2.06 & 1.44 \\
$\mathrm{C}_{2} \mathrm{H}_{6}$ & 0.21 & 0.14 & 0.09 & 0.05 & 0.16 & 0.11 & 0.07 & 0.04 \\
$\mathrm{C}_{2} \mathrm{H}_{2}$ & 0.06 & 0.09 & 0.13 & 0.16 & 0.41 & 0.41 & 0.37 & 0.33 \\
$\mathrm{CH}_{4}$ & 2.94 & 2.38 & 1.89 & 1.66 & 4.15 & 3.26 & 2.63 & 2.07 \\
$\mathrm{C}_{3} \mathrm{H}_{6}$ & 0.43 & 0.27 & 0.15 & 0.08 & 0.34 & 0.22 & 0.13 & 0.04 \\
$\mathrm{C}_{3} \mathrm{H}_{4}$ & 0.11 & 0.08 & 0.02 & 0.02 & 0.04 & 0.03 & 0.01 & 0.01 \\
$\mathrm{C}_{6} \mathrm{H}_{6}$ & 0.44 & 0.38 & 0.35 & 0.34 & 1.05 & 0.88 & 0.22 & 0.55 \\
$\mathrm{~N}_{2}$ & 53.39 & 58.64 & 64.63 & 65.86 & 63.70 & 67.19 & 69.62 & 73.60 \\
\hline
\end{tabular}

508

509

510

511 Table S.2: Syngas composition at the gasifier outlet depending on the SRF for different temperatures.

\begin{tabular}{|c|ccc|cccc|}
\hline SRF & \multicolumn{5}{c|}{ SRF1 } \\
\hline $\mathbf{T}\left({ }^{\circ} \mathbf{C}\right)$ & $\mathbf{7 5 5}$ & $\mathbf{8 2 5}$ & $\mathbf{8 8 0}$ & $\mathbf{7 7 5}$ & $\mathbf{8 1 0}$ & $\mathbf{8 5 0}$ & $\mathbf{9 0 5}$ \\
$\mathrm{H}_{2}$ & 6.08 & 6.70 & 9.55 & 2.63 & 3.31 & 4.09 & 6.61 \\
$\mathrm{O}_{2}$ & 0.13 & 0.08 & 0.00 & 0.08 & 0.04 & 0.01 & 0.49 \\
$\mathrm{CO}$ & 5.56 & 8.00 & 15.63 & 6.05 & 6.18 & 6.67 & 8.54 \\
$\mathrm{CO}_{2}$ & 16.48 & 15.60 & 11.96 & 14.37 & 14.08 & 13.63 & 13.38 \\
$\mathrm{C}_{2} \mathrm{H}_{4}$ & 1.31 & 1.55 & 1.75 & 2.50 & 2.55 & 2.264 & 1.45 \\
$\mathrm{C}_{2} \mathrm{H}_{6}$ & 0.19 & 0.14 & 0.11 & 0.14 & 0.11 & 0.06 & 0.04 \\
$\mathrm{C}_{2} \mathrm{H}_{2}$ & 0.04 & 0.09 & 0.15 & 0.35 & 0.41 & 0.48 & 0.02 \\
$\mathrm{CH}_{4}$ & 2.03 & 2.38 & 3.00 & 2.90 & 3.26 & 3.30 & 3.01 \\
$\mathrm{C}_{3} \mathrm{H}_{6}$ & 0.47 & 0.27 & 0.12 & 0.39 & 0.22 & 0.06 & 0.02 \\
$\mathrm{C}_{3} \mathrm{H}_{4}$ & 0.02 & 0.08 & 0.00 & 0.04 & 0.03 & 0.02 & 0.01 \\
$\mathrm{C}_{6} \mathrm{H}_{6}$ & 0.34 & 0.38 & 0.50 & 0.66 & 0.88 & 1.10 & 1.07 \\
$\mathrm{~N}_{2}$ & 63.70 & 58.64 & 50.24 & 69.63 & 67.19 & 64.99 & 59.46 \\
\hline
\end{tabular}




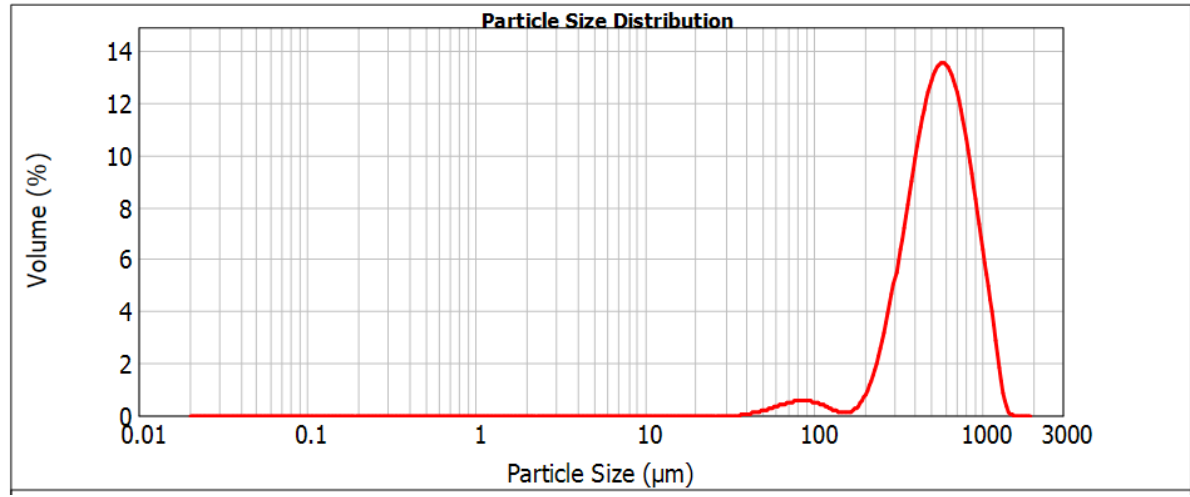

Figure S.1: Particle size distribution of fresh olivine. 